\title{
Anatomo-Histological Evaluation of Male Reproductive System of the Juvenile Caiman crocodilus yacare
}

\author{
Evaluación Anátomo-Histológica del Sistema Reproductor \\ del Caiman crocodilus yacare Macho Juvenil
}

\author{
Cristiane Naoko Takamine ${ }^{1}$; Hianka Jasmyne Costa de Carvalhoㅜㄹ Michelle Silva Araújo; \\ Rafaela Rodrigues Ribeiro ${ }^{1}$; Maria Angélica Miglino ${ }^{1}$ \& Alan Peres Ferraz de Melo²
}

\begin{abstract}
TAKAMINE, C. N.; CARVALHO, H. J. C.; ARAUJO, M. S.; RIBEIRO, R. R.; MIGLINO, M. A. \& DE MELO, A. P. F. Anatomohistological evaluation of male reproductive system of the juvenile Caiman crocodilus yacare. Int. J. Morphol., 39(6):1688-1693, 2021.

SUMMARY: The Caiman crocodilus yacare was once close to extinction. Studies about the male reproductive tract may aid in their reproduction and conservation. In this work, after sedation and euthanasia, seven young male $C$. yacare were submitted to necropsy, and macroscopic evaluation of the reproductive system, while the three others were admitted for histological study. The histological sections were stained with Hematoxylin \& Eosin and Masson's Trichrome. After opening the pleuroperitoneal cavity it was possible to identify that the testicles were disposed in pairs and attached to its dorsal surface. The epididymis showed elongated and convoluted shapes and were located at the cranial margin of the testicles, following its medial portion, which was the same portion that the "vas deferens" stems from until the opening of the cloaca. The crocodile phallus presented a tubular shape, with conical appearance, displaying little resistance while maintaining its flexibility, compatible with a fibrocartilaginous tissue. On light microscopic analysis it was possible to observe that the testis was delimited by the tunica albuginea. The seminiferous tubules were contorted, and the interstitial space was filled with interstitial tissue and Leydig cells. The epididymal ductus were covered with non-ciliated pseudostratified epithelium with cells varying between cuboidal and prismatic shapes. The ductus deferens were characterized by a narrow girth shrouded with nonciliated pseudostratified prismatic epithelium. The phallus of the crocodile was covered with a non-keratinized squamous epithelium surrounded by connective tissue. The findings support anatomic and histologic knowledge Alligatoridae reproductive system, enabling further research in the $C$. yacare reproduction and conservation.
\end{abstract}

KEY WORDS: Crocodilian; Male; Sexual organs; Anatomy; Histology.

\section{INTRODUCTION}

Due to human exploration of the fauna and flora, the natural Biomes have become irrevocably degraded, favoring endangerment and extinction of multiple species. One of those endangered animals is the "Jacaré-do-Pantanal", scientifically classified as Caiman crocodilus yacare $(C$. yacare), which was almost extinct in the 1960s. The $C$. yacare is morphologically and ecologically similar to the common caiman (Caiman crocodilus crocodilus), and inhabits Bolivia, Paraguay, Northeastern Argentina, Southwestern Brazil and Northwestern Uruguay (Marioni et al., 2008). As the common caiman, C. yacare is found in a wide spectrum of habitat types. The Pantanal region of Southern Brazil presents one of the most vigorous natural populations of crocodilians in the world, distributed throughout the Pantaneira plain (Mourão et al., 2000).

Crocodiles are generalist animals with a diverse diet and their principal sources of food are fishes, crustaceans, mollusks, and insects, further demonstrating the important role of these animals on the ecosystem balance (Campbell et al., 2008; Villamarín et al., 2011). The $C$. yacare is known for its highly valuable skin used in the manufacture of tissues and other leathery products, as well as for its meat that acts as an alternative source of protein, making this crocodile species a target for animal traffic and capitalization. The consumption of crocodile's meat is traditional in Brazil, with

\footnotetext{
${ }^{1}$ Department of Surgery, School of Veterinary Medicine and Animal Science, University of São Paulo, São Paulo, Brazil. Avenue Prof. Dr. Orlando Marques de Paiva, 87, University City, Butantã. São Paulo, SP, Brazil.

${ }^{2}$ Paulista State University Júlio Mesquita Filho, Department of Animal Science, São Paulo, Brazil. Avenue Prof. Paulo Donato Castellane, Jaboticabal, CEP: 14884-900, Brazil.

Funding Source: This study was supported by São Paulo Research Foundation, grant number: 2003/10397-3.
} 
TAKAMINE, C. N.; CARVALHO, H. J. C.; ARAUJO, M. S.; RIBEIRO, R. R.; MIGLINO, M. A. \& DE MELO, A. P. F. Anatomo-histological evaluation of male reproductive system of the juvenile Caiman crocodilus yacare. Int. J. Morphol., 39(6):1688-1693, 2021.

high demand in local markets. Furthermore, the exportation of its meat to exotic meat markets in developed countries is increasing; but the rational breeding of these animals is a relatively new activity; which means that the commercialization of $C$. yacare skin and meat is still considered a risk factor for its preservation (Aleixo, 2000; Saadoun; Cabrera, 2008). Regarding that, several conservation programs have been initiated with the participation of communities, private enterprises, and environmental authorities (Medrano-Bitar \& Rojano, 2009; Balaguera Reina, 2012).

Thus, the necessity of research to improve the understanding of the particularities of this species becomes clear, including its reproduction to conserve this endangered reptile, just as it has been done in other species of crocodiles. Since the reproduction system description of the $C$. yacare was reported only in adult animals (Coutinho, 2000), this investigation aims to describe both macroscopic and microscopic anatomy of reproductive system of the juvenile male $C$. yacare. The purpose of the present study is to assist in future research intended to preserve this species, guide new reproductive technologies, and increase a sustainable production in controlled environments of this crocodile providing for products and by-products commercialization, and extinguishing its hunting. Moreover, this study can serve as a guide to researchers concerning the reproductive system of other reptile members of the Crocodylidae family.

\section{MATERIAL AND METHOD}

Specimen collection and fixation. All husbandry and experimental procedures were approved by the Bioethics Committee of the School of Veterinary Medicine and Animal Science of University of São Paulo ([No.8382016]). The animals were euthanized according to the guidelines of approved protocol $\left(\mathrm{n}^{\mathrm{o}} 712\right.$ resolution of the Federal Council of Veterinary Medicine of Brazil).

Ten young male specimens of Caiman crocodilus yacare (from Reptilia class, Crocodilia order, Alligatoridae family and Caiman genus) aged between 24 and 42 months, were donated to attend a research purpose by a local producer from São Paulo State, Brazil. After the necropsy seven animals were submitted to macroscopic analysis of the reproductive organs. An incision was first made at the alba or white line followed by the exposure of the organs inside the pleuroperitoneal cavity. The intestines were secluded to promote a better observation of the genital organs. The male reproductive organs were identified using their topography and then dissected in situ enabling the anatomic description and registration by a camera of all male reproductive system structures.

The other three animals were submitted to microscopic evaluation of the reproductive organs. Fragments from the testis, epididymis, duct deferens, and the phallus were fixed in $4 \%$ paraformaldehyde and then histological processing was performed.

Histological processing. The samples were dehydrated and rehydrated in 70, 80, 90 and $100 \%$ alcohol solutions, diaphonized in xylol, and finally embedded in paraffin. Sections of $5 \mu \mathrm{m}$ were performed for the assembly of the slides followed by Hematoxylin \& Eosin [HE] and Masson's Trichrome $[\mathrm{MT}]$ staining techniques.

Image acquisition and processing. The slides were analyzed and photographed with an Olympus BX-60 optical microscope. The terminology used to identify the anatomical structures was the Nomina Anatomica Avium, since there is no specific denomination for the Crocodylidae family, and due to the evolutionary proximity between birds and reptiles.

\section{RESULTS}

Anatomy of the male reproductive system. The external ventral skin of the Caiman yacare was characterized by smooth dermal plates on its surface, and a shining yellowcreamy pigmentation. On the ventral region, externally to the medium line, there was an opening to the cloaca cavity (Fig. 1A). Through palpation, the cloaca cavity exhibits the phallus enclosed, showing its ability to retract and progress (Fig. 1B). However, the observation of the copulatory organ is difficult to perform in a resting state. This copulatory organ presented a conical shape and white color, containing a groove for the ejaculatory duct (Fig. 1C) that allows the sperm deposition in the external environment or inside the female vans.

All animals showed a pair of testicles, epididymis, vas deferens and a single copulatory organ, disposed in the pleuroperitoneal cavity (Fig. 1D). The testicles were bilateral structures arranged on each side of the pleuroperitoneal cavity, deriving from the median line. The right testicle was bigger and located cranially than the left one. However, both structures were compacted, and elongated in shape. On young and prepubertal animals, the testicle pigmentation was also creamyyellow. The position of the testis in the cavity was craniallyventral related to the kidney, being cranially closer to the surface of the gastric ventricle. Medially, the testes were adjoining to blood vessels such as the aorta and the caudal cava vein. Its caudal-dorsal position was near the bowels (Fig. 1D). 


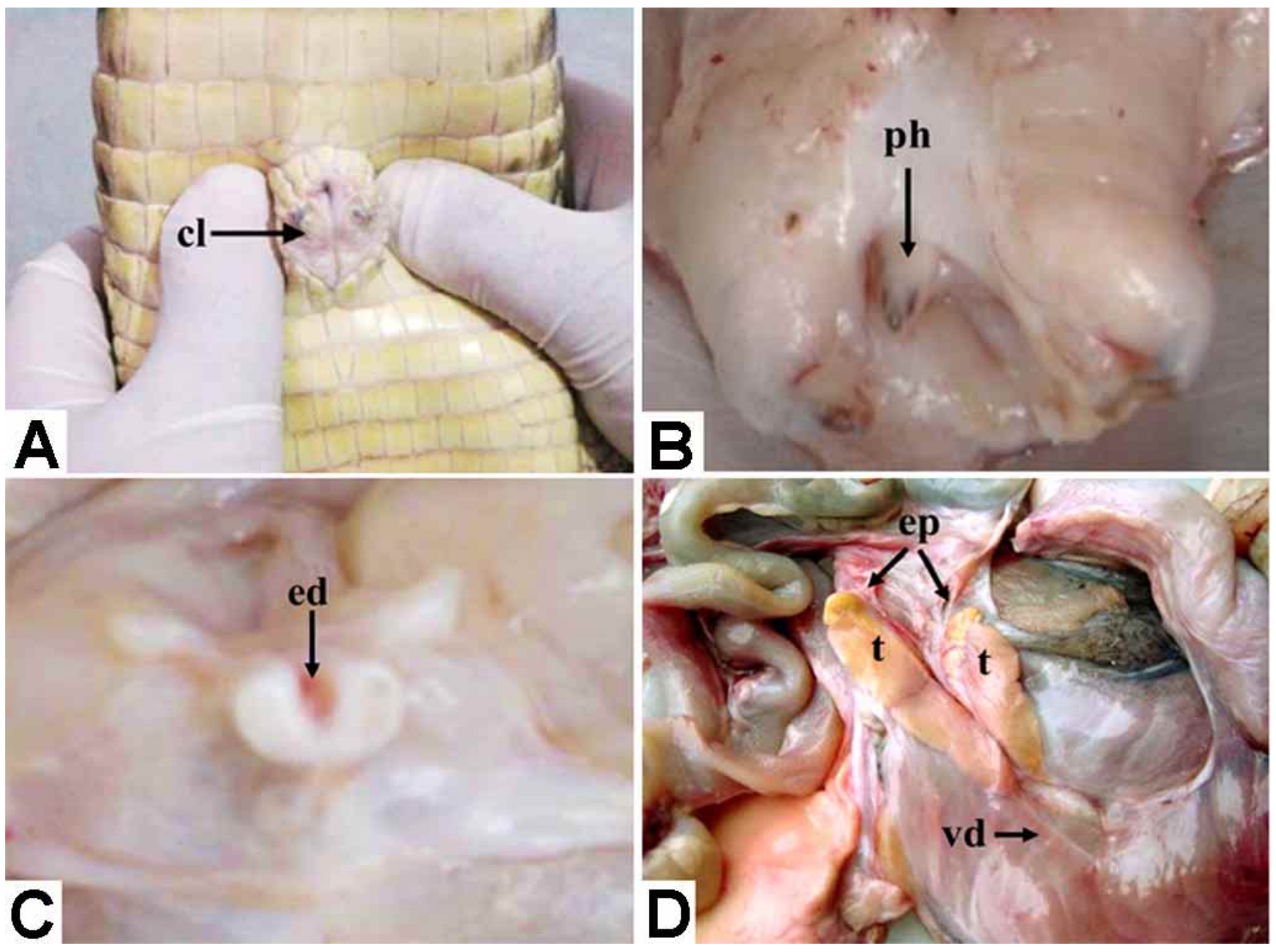

Fig. 1. Male reproductive system of the Pantanal-Crocodile (Caiman crocodilus yacare). A - The Cloaca or ventral cavity opening (cl); $\mathrm{B}$ - Exhibition of the phallus (ph) in the ventral cavity; C - Transversal section of the phallus revealing the ejaculatory duct (ed); D Pleuroperitoneal cavity organs, the pair of testicles (t), the epididymis in the cranial portion (ep) and the vas deferens (vd).

The epididymis was yellowish and presented an elongated and fusiform shape on its cranial portion, becoming filamentous from its middle third until its caudal margin. Adjacent to the medial surface of its caudal portion, the vas deferens was present, forming a long sinuous and almost imperceptible tubule (Fig. 1D). The "vas deferens" originates from the caudal section of the epididymis and were macroscopically identified as a thinner structure running through the medium line (Fig. 1D), in adjacency to the ureter until the cloaca cavity.

Microscopic analysis of the male reproductive system. On the histological analysis it was observed an adrenal gland attached to the testicle and the epididymis (Fig. 2A). The testicles were delimited by the tunica albuginea (Fig. 2B), a fibrous capsule composed by a connective tissue, which is rich in collagen fibers (Fig. 2C). The testis interior was formed by seminiferous tubules (Fig. 2D) separated by a space filled with connective tissue, blood vessels and Leydig or interstitial cells (Fig. 2E). Leydig cells were located at the interstitial space, being characterized by polyhedral cells, with scarce and eosinophilic cytoplasm (Fig. 2E). Seminiferous tubules were lined by a seminiferous epithelium consisting of two principal types of cells, the Spermatogonial Stem Cells (SSC's) and Sertoli cells. These SCC'S were observed along the basement membrane of the seminiferous tubules (Fig. 2F), however, they were not able to be distinguished in the $C$. yacare specimens due to their young age.

The Sertoli cells have extended from the seminiferous tubules basement membrane to the tubular lumen, and were histologically characterized by elongated-shape cells, frequently vacuolated cytoplasm, with round to elongated nuclei. Additionally, myofibroblastic cells were observed adjacent to the seminiferous epithelium (Fig. 2F). 
The space between the seminiferous tubules was filled with connective tissue and Leydig cells. The Leydig cells nuclei were round to polyhedric, with coarse chromatin (Fig. 2G). The rete testis was a central collector tubule that connects the seminiferous tubules to the efferent ductus. This connection consists of an encasing cubical epithelium and a thin layer of connective tissue (Fig. 2H).

Regarding the epididymis, the microscopic analysis of the efferent ductus revealed that this one delimits a relatively broad light of regular contours. Internally lined with a non-ciliated pseudostratified epithelium composed of basal cells varaying between cubic and prismatic cells (Fig. 2I). Thin connective tissue layers covering the basal lamina and are surrounded by a single or double layer of round muscular tissue (Fig. 2J).

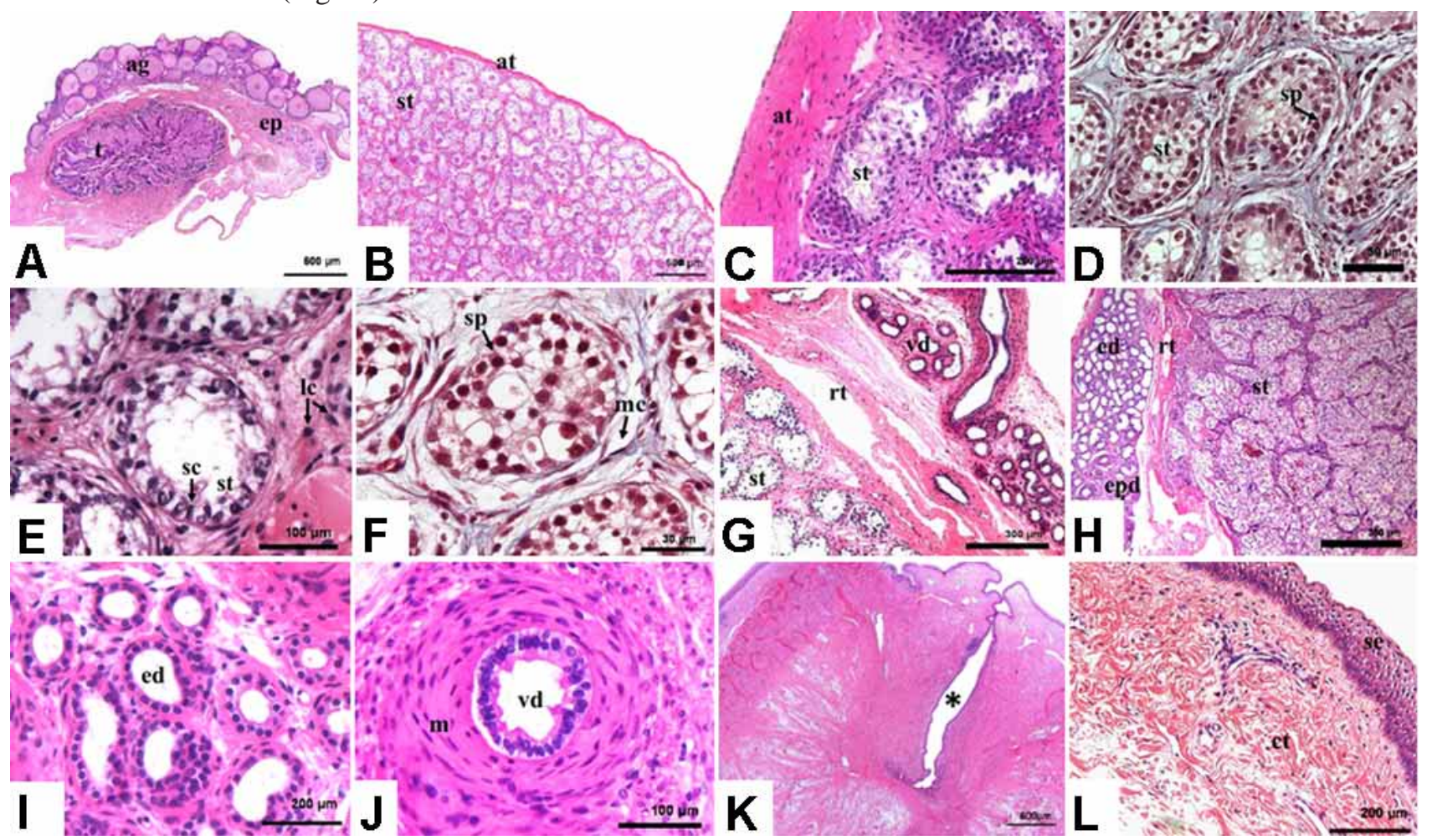

Fig. 2. Histology of the sexual organs of the Caiman crocodilus yacare. A - Photomicrograph displaying the adrenal gland (ag) of the C. yacare attached to the testicle (t) and epididymis (ep) [Hematoxylin-Eosin stain]; B - Microscopy of the testicle; tunica albuginea (ta) encapsulating the seminiferous tubules (st) [Hematoxylin-Eosin stain]; C - tunica albuginea (ta) and seminiferous tubules (st) [Hematoxylin-Eosin stain]; D Seminiferous tubules (st) with proliferation of non-differentiated spermatogonial stem cells (sp) [Masson's Trichrome stain]; E - Seminiferous tubules (st), Sertoli cells (sc) and interstitial Leydig cells (lc) [Hematoxylin-Eosin stain]; F - Non-differentiated Spermatogonial stem cells (sp) within seminiferous tubules surrounded by myofibroblasts cells (mc) [Masson's Trichrome stain]; G - Seminiferous tubules (st), the vas deferens (vd) and the rete testis (rt) connecting the seminiferous tubules with the efferent ductus [Hematoxylin-Eosin stain]; $\mathrm{H}$ - Seminiferous tubules (st), rete testis (rt), efferent ductus (ed) and epididymal ductus (epd) [Hematoxylin-Eosin stain]; I - Efferent ductus (ed) with cubic and prismatic epithelium; $\mathrm{J}$ - vas deferens (vd) composed by non-ciliated prismatic pseudostratified epithelium, with a thick adjacent muscular layer (m) [Hematoxylin-Eosin stain]; K - Photomicrography of the phallus, showing the ejaculatory duct $(*)$ [Hematoxylin-Eosin stain]; L - Phallus, displaying the region composed by non-keratinized squamous epithelium (se), shrouded by unmodified thick dense connective tissue (ct) [Masson's Trichrome stain].

List of Abbreviations AG: adrenal gland; CL: The Cloaca or ventral cavity opening; CT: connective tissue; ED: ejaculatory duct; EP: epididymis; EPD: epididymal ductus; LC: Leydig cells; PH :phallus; M: muscular layer; MC: myofibroblasts cells; RT: rete testis; SP: Spermatogonial Stem Cells; ST: seminiferous tubules; T: testicles; TA: tunica albuginea; VD: vas deferens. 


\section{DISCUSSION}

The male reproductive organs of Caiman crocodilus yacare, even though well-described in adult specimens, lack of essential information in young ones. Thus, this is the first study describing the anatomy and histology of the juvenile C. yacare.

The testes on the young $C$. yacare were bilateral structures, assembled on each side of the medium line, in accordance with previously described in the Caiman crocodilus fuscus (Guerrero et al., 2004), and adult specimens of the Caiman crocodilus yacare (Coutinho). For Coutinho, the left testicle of $C$. yacare is bigger and localized cranially to the right one, which is smaller and located caudally compared to its contralateral match. According to the present investigation the differences among the size and topography of the reproductive system in the $C$. yacare is already present during the young ages.

In the immature model of $C$. yacare, without sexual maturity, it was possible to observe a creamy-yellow color of the testis. A fibrous capsule of connective tissue originates from the tunica albuginea that covers the testicle. The seminiferous tubules present Sertoli cells and SSC's, resembling the Coutinho description. However, the spermatogonial cells were undifferentiated, an important finding considering the reproductive research to study the culture of undifferentiated SSC's in vitro, and the possibility future development of these cells in Pluripotent Embryonic Stem Cells for reproductive purposes (Kubota \& Brinster, 2006). Another original finding in young $C$. yacare is the "rete testis", that are ductules covered by a cuboidal epithelium, with a coating layer of thin connective tissue that bridges the seminiferous tubules to the efferent ductules; different from the rete testis described in other crocodilians and fowl animals (Lake, 1981; Bacha \& Bacha, 2003; Guerrero et al.).

The characteristics of the epididymis structure were similar to previously described by the scientific literature (Coutinho; Guerrero et al.). They were coated by a nonciliated pseudostratified epithelium, with basal cells varying from cubic to a prismatic shape. The "vas deferens" of the specimens were alike in morphology call aspects to those described by King (1986) and Dyce et al. (2004), for domestic birds. As the present study, in these researches it was also possible to observe that the vas deferens of the $C$. yacare is continuous to the epididymal ductule, that has its internal layer composed by non-ciliated pseudostratified prismatic epithelium, resembling the epididymis epithelium. This observation has been previously described by Bacha \&
Bacha, who also observed thick muscular tissue layers dividing the internal and external sub-layers.

Considering that current reproductive technologies such as in vitro culture of undifferentiated SSC's which is used for species preservation, rely on anatomical and microscopic knowledge to assess their success, these results are essential to promote the conservation of the $C$. yacare. These data are even more relevant when considering that undifferentiated SSC's are easily collected from young animals like the $C$. yacare specimens ones used in the study.

\section{ACKNOWLEDGEMENTS}

The authors are grateful to FAPESP (São Paulo Research Foundation)) for the financial support and to CAPES (Coordination for the Improvement of Higher Education Personnel).

The authors also would like to thank Mister Osvaldo Roberto Scabine for donating the animals used in this research. Acknowledgements are also in place for the Msc. Pathologist Expert Leonardo Lima Gorza for his help with the histology analysis review.

TAKAMINE, C. N.; CARVALHO, H. J. C.; ARAUJO, M. S.; RIBEIRO, R. R.; MIGLINO, M. A. \& DE MELO, A. P. F. Evaluación anatomo-histológica del sistema reproductor masculino del Caiman crocodilus yacare juvenil. Int. J. Morphol., 39(6):1688-1693, 2021.

RESUMEN: El Caiman crocodilus yacare ha estado en peligro de extinción. Los estudios sobre el aparato reproductor del macho pueden ser de ayuda en su reproducción y conservación. En este trabajo, fueron sometidos a necropsia y evaluación macroscópica del aparato reproductor, siete machos jóvenes de $C$. yacare, mientras que otros tres fueron utilizados para su estudio histológico. Las secciones histológicas se tiñeron con hematoxilina y eosina y tricrómico de Masson. Después de examinar la cavidad pleuroperitoneal se pudo identificar que los testículos estaban dispuestos en pares y adheridos a su superficie dorsal. El epidídimo presentaba formas alargadas y contorneadas y se ubicaba en el margen craneal de los testículos, siguiendo su porción medial, que era la misma porción de donde parten los conductos deferentes hasta la apertura de la cloaca. El pene del cocodrilo presentaba forma tubular, de apariencia cónica, mostrando poca resistencia manteniendo su flexibilidad, compatible con un tejido fibrocartilaginoso. En el análisis microscópico óptico se pudo observar que el testículo estaba delimitado por la túnica albugínea. Los túbulos seminíferos estaban contorsionados y el espacio intersticial estaba lleno de tejido intersticial y células intersticiales (células de Leydig). El epidídimo estaba cubierto con epitelio pseudoestratificado no ciliado con células que variaban entre for- 
mas cuboideas y prismáticas. Los conductos deferentes se caracterizaron por una circunferencia estrecha envuelta en un epitelio prismático pseudoestratificado no ciliado. El pene del cocodrilo estaba cubierto con un epitelio escamoso no queratinizado rodeado de tejido conectivo. Los hallazgos corroboran el conocimiento de la anatomía del sistema reproductivo de Alligatoridae, lo que permite una mayor investigación sobre la reproducción y conservación de $C$. yacare.

PALABRAS CLAVE: Cocodrilo; Masculino; Órganos sexuales; Anatomía; Histología.

\section{REFERENCES}

Aleixo, V. M. Efeitos do Uso de Farelo de Soja e de Sistemas de Alimentação sobre o Desempenho de Filhotes de Jacaré-do-Pantanal Caiman yacare (Daudin, 1802). Dissertação de Mestrado. Lavras, UFLA, 2000.

Bacha, W. J. \& Bacha, L. M. Atlas Colorido de Histologia Veterinária. 2nd ed. São Paulo, Rocca, 2003. pp.338, 351-3.

Balaguera Reina, S. A. Relaciones etno-zoológicas, hábitat y estructura poblacional de Caiman crocodilus fuscus en las ciénagas Zapatosa y Costilla, Departamento del Cesar, Colombia. Herpetotropicos, 8(1-2):5$12,2012$.

Campbell, H. A.; Micheli, M. A. \& Abe, A. A seasonally dependent change in the distribution and physiological condition of Caiman crocodilus yacare in the Paraguay River Basin. Wildl. Res., 35(2):150-7, 2008.

Coutinho, M. E. Population ecology and the conservation and management of Caiman yacare in the Pantanal, Brazil. PhD Thesis. Queensland, Department of Zoology and Entomology, University of Queensland, 2000 .

Dyce, K. M.; Sack, W. O. \& Wensing, C. J. G. Anatomia das Aves. In: Dyce, K. M.; Sack, W. O. \& Wensing, C. J. G. (Eds.). Tratado de Anatomia Veterinária. 3rd ed. Rio de Janeiro. Elsevier, 2004. pp.7901.

Guerrero, S. M.; Calderón, M. L.; de Pérez, G. R. \& Ramírez Pinilla, M. P. Morphology of the male reproductive duct system of Caiman crocodilus (Crocodylia, Alligatoridae). Ann. Anat., 186(3):235-45, 2004.

King, A. S. Aparelho Urogenital das Aves. In: Getty, R. (Ed.). Sisson Grossman: Anatomia dos Animais Domésticos. 5th ed. Rio de Janeiro, Guanabara Koogan, 1986. pp.1805-12.

Kubota, H. \& Brinster, R. L. Technology insight: In vitro culture of spermatogonial stem cells and their potential therapeutic uses. Nat. Clin. Pract. Endocrinol. Metab., 2(2):99-108, 2006.

Marioni, B.; Da Silveira, R.; Magnusson, W. \& Thorbjarnarson, J. Feeding behavior of two sympatric caiman species, Melanosuchus niger and Caiman crocodilus, in the Brazilian Amazon. J. Herpetol., 42(4):76872, 2008.

Medrano-Bitar, S. A. \& Rojano, A. M. Conservation program, sustainable use and management of some wetlands in the State of Atlántico, Phase II Corporacion Regional del Atlantico (CRA). Gland, Proceedings of the 19th Working Meeting of the IUCNSSC Crocodile Specialist Group, 2009. pp.94-9.

Mourão, G.; Coutinho, M.; Mauro, R.; Campos, Z.; Tomás, W. \& Magnusson, W. Aerial surveys of caiman, marsh deer and pampas deer in the Pantanal Wetland of Brazil. Biol. Conserv., 92:175-83, 2000.

Villamarín, F.; Marioni, B.; Botero-Arias, R.; Thorbjarnarson, J. B. \& Magnusson, W. E. Conservation and management implications of nestsite selection of the sympatric crocodilians Melanosuchus niger and Caiman crocodilus in Central Amazonia, Brazil. Biol. Conserv., 144:913-9, 2011.
Corresponding author:

Maria Angélica Miglino

Department of Surgery

School of Veterinary Medicine and Animal Science

University of São Paulo

Avenue Prof. Dr. Orlando Marques de Paiva, 87

University City

Butantã

São Paulo

BRAZIL

E-mail: miglino@usp.br

Cristiane Naoko Takamine: cntakamine@yahoo.com.br Hianka Jasmyne Costa de Carvalho: hiankacarvalho@usp.br Michelle Silva Araujo: msa.vet@hotmail.com

Rafaela Rodrigues Ribeiro: rafaelarodriguesribeiro@usp.br Alan Peres Ferraz de Melo: alan.melo@unesp.br

Received: 21-07-2021

Accepted: 29-08-2021 